\title{
ESSAY
}

\section{Two Functions of Formalism}

\author{
In Memory of Guido Tedeschi
}

Guido Calabresi $\uparrow$

\begin{abstract}
Some thirty years ago, I gave a lecture on the Italian legal system. It was meant to be an informal explanation, to an American-primarily university-audience, of some aspects of Italian jurisprudence that might seem puzzling to those accustomed to U.S. views of law. In a recent article, Professor Cass Sunstein referred to my unpublished talk, and the editors of The University of Chicago Law Review asked me to send them a copy for citechecking purposes. After reading the essay they decided that it was worth publishing and urged me to let them do so. I agreed. To be told that an after-dinner chat still had some interest for readers thirty years later was flattery that I could not resist.
\end{abstract}

For a while I thought about rewriting and updating the essaythere are, after all, many things that have happened in both American and Italian law since I gave the talk that are relevant to it. To what degree has the movement toward express functionalism advanced in Italy? What is the significance of the abject failure in American capital cases of the attempt to impose a modicum of order in sentencing? $?^{2}$ Has our legal system been materially altered in relevant ways by the establishment of federal sentencing guidelines? To what extent has the influence of Justice Antonin Scalia's jurisprudence moved us closer to a "gold standard" view of law? One could give sound-bite answers to each of these: "to a fair degree"; "a predictable return to jury aresponsibility"; "less than one might think"; and "some, but not as much as he hopes." Such replies would, however, be woefully inadequate. And to treat

$\dagger$ Judge, United States Court of Appeals for the Second Circuit; Sterling Professor of Law Emeritus and Professorial Lecturer, Yale University Law School. (1999).

1 See Cass R. Sunstein, Must Formalism Be Defended Empirically?, 66 U Chi L Rev 636

2 See Callins v Collins, 510 US 1141 (Scalia concurring in denial of certiorari) and id at 1143 (Blackmun dissenting from denial of certiorari). 
properly these, not to mention a multitude of other possible, updating questions would require a full-length article apiece. So I decided to let the essay stand unchanged-as a somewhat dated, but perhaps still relevant, rumination about law and formalism.

Similarly, I resisted the temptation to make it read more like an article by adding all manner of citations. A few bibliographic notes may nevertheless be worthwhile. The case of the Bolognese doctor appears in Puffendorf, and gets picked up by Blackstone. It is also mentioned from time to time in American law. ${ }^{3}$ The ideal-preservation function of law, but not its express link to formalism, is discussed at length in Calabresi and Bobbitt, Tragic Choices (Norton 1978). That link, between formalism and ideal preservation, is significantly responsible for the views I expressed in my concurring opinion in Benjamin $\mathrm{v}$ Jacobson. ${ }^{4}$ Most importantly, the relationship of formalism to democracypreserving conservatism has been examined recently in an important article by Professor (now Justice) Izhak Englard. ${ }^{\text {s}}$

It is, I think, no accident that Justice Englard's teacher was a great Italian-Israeli formalist, Guido Tedeschi, who was Giorgio Del Vecchio's nephew and rebelled against Del Vecchio's functionalism (as well as his Fascism). ${ }^{6}$ Influences on legal thought are by no means linear, however, and among Tedeschi's devoted pupils are also three other Justices of the Israeli Supreme Court, including the President of that Court, Aharon Barak. That Tedeschi appreciated that both formalism and functionalism have their roles to play in the cathedral of law can be seen not only in his great affection and esteem for Chief Justice Barak and for Barak's work, but also in a letter that Tedeschi wrote his (then) young cousin, the author of this piece, on the occasion of the publication of Some Thoughts on Risk Distribution and the Law of Torts. ${ }^{7}$ After noting that this article-which was in part responsible for the renaissance of the law and economics movement-was "far different" from his own approach to law, Tedeschi added that it clearly shed new light and that is all that matters in legal scholarship.

See, for example, Ross v Hartman, 139 F2d 14 (DC Cir 1943).

172 F3d 144, 180 (2d Cir 1999) (Calabresi concurring) ("In the context of the Separation of Powers, it is the formal independence of the courts that is safeguarded by an absolute rulenever before infringed-that says that court judgments are not to be touched by the legislative and executive branches. The basic power to legislate (and to enforce that legislation) in the public interest is not undercut by this formal rule (that is, the power to achieve a result in terms of prisoners' rights is unaltered), but the dignity of the courts qua courts is protected by it.").

5 See Izhak Englard, Nazi Criticism Against the Normativist Theory of Hans Kelsen: Its Intellectual Basis and Post-Modern Tendencies, 32 Israel L Rev 183 (1998).

6 See Izhak Englard, Guido (Gad) Tedeschi at Eighty: A Tribute, 21 Israel L Rev 247 (1986).

770 Yale L J 500 (1961). 
It is in the open spirit of Guido Tedeschi that I publish the essay, dedicating it to the memory of a scholar who understood deeply the functions of formalism.

To the average American, Italy's approach to law is a puzzle. The Italian's casual contempt for legal rules in practice baffles the, by contrast, extraordinarily law-abiding American almost as much as does the respect given to law in Italy when it is viewed only as a theoretical system. So viewed, it is not to be tinkered with, or even criticized by legal scholars, merely because it does not serve social goals. Indeed, for an Italian scholar to ask questions as basic to American legal scholarship as "What ends does a law serve?" or "What ought a law be?" seems almost to verge on the improper. How did these attitudes come about; are they as strong today as in the past; and are they likely to remain dominant? These are the questions I would like to talk about with you today.

It wasn't always this way. Every schoolboy knows that the Italian universities, and especially Bologna, were the great centers of nonreligious law throughout the Middle Ages and beyond. Indeed, there may well have been no break at all between the ancient Roman law schools in Bologna and the University of Bologna. What is not generally known, however, is how modern law was in Italy at that time, at least in contrast to what was happening in England. For instance, in the Middle Ages in Italy, in Bologna, someone passed a law against shedding blood in the streets. The object of the law, I guess, was dueling, roughhousing, that kind of thing. It happened one day that a man was walking down the streets of Bologna and collapsed. He was sick; a doctor came along and, according to accepted medical practice, bled him, thus shedding blood in the streets. A policeman, seeing that the law as written was broken, arrested the doctor and brought him before a judge. The judge said what seems perfectly normal to us today, "that wasn't what the law was about. He did shed blood in the streets, but it had nothing to do with why the law was passed." And he let the doctor go. That is a typical example of a functional approach to law. The court looked not at the language of the law, but only to what the law was supposed to do. At that time in most other countries, such an approach would not have been thought of.

The functional approach to law, law as a "doer" of things, continued to remain very important in Italy throughout the Renaissance and into the Enlightenment. Beccaria's discussion of criminal law in the eighteenth century, which talked about why criminal law, what it did, and therefore what types of criminal punishments were justified, is a perfect example. This attitude continued throughout the early nine- 
teenth century. Thus, the law reforms brought about by the French Revolution and the great Codifications that followed it closely reflected notions of what ends the law ought to serve.

Toward the end of the nineteenth century, however, the codes and law generally became rigidified. German influences, which came to the United States too, though here there were other influences as well, came to be felt. The scholars who followed this approach propounded a notion of law as a science, with a logic of its own. Law came to be viewed as a formal legal system answering to strict rules. And legal scholarship was asked to look not to the functions law served, what it was supposed to do, but only to the internal consistency of the system.

In the United States this approach started breaking down in the first thirty or forty years of the twentieth century. People started realizing that the laws enforced served nineteenth-century social goals, and began asking what kinds of laws, or what kind of law reform, could make the law answer to the social goals of the present, of the twentieth century.

Perhaps the same would have occurred in Italy, had it not been for the coming of Fascism, and that, in a way, is the essence of our story. To the scholars opposing Fascism, the nineteenth-century selfcontained formalistic system became a great weapon. Why? Well, a formal, self-contained, uncriticizable system of law is conservative. It can't be changed. Now, what did it conserve in Italy in the 1920s? What it conserved was the liberal, nineteenth-century political approach, as well as nineteenth-century economic laissez-faire. But, in a time of Fascism, the important thing was that it conserved basic democratic attitudes.

The functionalists, those who wanted law to be responsive to social goals, were in the 1920s necessarily Fascists, because in the 1920s and ' 30 s, the goals of the society, since it was totalitarian and Fascist, could only be stated in terms of Fascist ideology. So it is no accident actually that the great American functionalist, Roscoe Pound, the Dean of the Harvard Law School, who was rather a liberal in many of these things, was a close friend of the most famous of the Italian functionalists, Giorgio Del Vecchio, Dean of the Law School at Rome, and later President of Rome University, who was in fact a Fascist. He was the most responsible of these Fascists, but, more important to Pound, he was one of the few Italian legal scholars who could talk Pound's language and let law answer to social goals.

The anti-Fascist scholars, by contrast, took defense in the fact that law could not be changed. Thus, in a broader sense Italian legal formalism, in its unresponsiveness, sterility if you wish, was itself serving a much greater constitutional function-that of preserving a democratic legal system from Fascist pressures. 
Well, as one would expect, the fall of Fascism changed things dramatically. And one might think that it would have totally changed this attitude toward law. For some it did; some of the people who had been traditionalists - formalists in their view of law, like Ascarelli and Calamandrei, and their students - at the very end of Fascism made clear that now the only thing that a formal system of law preserved was nineteenth-century economic ideals. Formalism was no longer necessary to preserve democratic freedoms, and therefore, one must look beyond Fascism to what law could do to order the society in terms of modern-day goals.

For others, however, the identification of functional law-of law which served purposes, of law which did things-with Fascism, remained too strong. And the fear that any law that responded to social ends, even if now the social ends were democratic, might in the future be corruptible to bad social ends, continued to have an influence. In a way, these people said, it is better to have a legal system that cannot change, than to put it in the hands of human beings who are fallible.

There is an analogue, I suppose, to people who like the gold standard. The greatest inflations and depressions in the world's history have been under the gold standard due to the rise and fall of the supply of gold, which was essentially outside human control. I suppose those who like a formalistic system of law believe that there is less danger from something that is not within human control than from something that can be made to do what human beings want. Because sometimes, what human beings want might be Fascism.

Well, of course, this conflict, between those like Ascarelli and Calamandrei, who said it was now time to make law respond to social ends, and the others, who continued to identify functional law with Fascism, couldn't be won totally by one side or the other. In the newer areas of law, the group that took what one might think of as an American approach to law tended to win out. This is seen most dramatically in the establishment of a constitutional court and in the growth of "constitutional law" in Italy.

This was a very real response of a functional sort to Fascism. There had been no tradition in Italy of a Supreme Court that could hold laws unconstitutional because they violated fundamental rights; that had been totally alien. And so when a great Chief Justice, Mortara, (actually even the term Chief Justice is inappropriate; he was the head of the Corte di Cassazione) in the early days of Fascism tried to do something much like what the American Supreme Court does in holding unconstitutional acts that go beyond the range of the acceptable legislative power, he failed because there was no legal tradition to support him. 
Immediately after the War, when the Italian Constitution was rewritten, it was provided that there should be a Constitutional Court. It took a while for the judges of the constitutional court actually to be appointed, something like ten years, which means that the court has been functioning for only the last twenty years. But today one can look at the cases before the Italian Constitutional Court and see almost all of constitutional history, two hundred years of American issues, concentrated in twenty years in Italy-and that is kind of fun. All the issues of equal protection of laws (whether you are treating women as well as men if there is a law that allows only women to teach in kindergartens and so on), all these issues, that American constitutional lawyers know all too well, came up in Italy in a very short period of time.

This includes, incidentally, the very knotty issue of central government as against regionalism. The starting point was different. Italy had been a centralized state since the 1860 s, 1870s. The Constitution after the Second World War provided for some semi-autonomous regions, and it was interesting to see whether these could behave autonomously against the tradition of centralization. In the United States, when our Constitution was enacted, the tradition was of sovereign, separate states, and the question was: "Could the constitution bring them together into one union?" The great Chief Justice Marshall was known for his federalization, for his unification of law, in the early days, to make one country out of these states. In Italy, the supreme court (the Constitutional Court) began in exactly the opposite way - to protect the regions from a tradition of centralization. After a while it learned what had been learned very early in the United States-that regionalization could quickly lead to a splitting apart. And when the Supreme Court of Sicily (a few years after the Constitutional Court had started sitting) declared that it was the final arbiter of law in Sicily regardless of national law, then the Constitutional Court in Italy, in an opinion that sounds very much like John Marshall's opinion in Martin v Hunter's Lessee, said no, the central government is the supreme federal government and must dominate.

Well, all this is very functional. It is very much like American law and it is characteristic of what happened in the newer areas, not only constitutional law and constitutional criticisms, all of which arose after the fall of Fascism, but also newer areas of law like labor law, tax law, and so on. In the classic areas like criminal law and civil responsibility (torts, accidents, contracts), however, the old ways die hard, and understandably so. These were the areas for which there was more of a tradition of formalism. These were also the areas where formalism had been a tremendous barrier against attempts to impose Fascist doctrine on the legal system. 
Still, if this were all that there were to it, we would expect a fairly quick rapprochement. As the defensive role of law required by Fascism faded more and more into memory, one would find more and more people who would be optimistic about making law respond to social goals. In time, they would win out. And the formalists, those who remembered the past, would probably tend to lose ground. But there is another aspect of Italian law, and of Italian views toward law, that may make any such rapprochement less likely. And that incidentally may account for the contempt of law in practice that I alluded to earlier, as well as for its theoretical untouchability.

There is another function of law, one we do not think of too much in the United States, and that is the role of law as a stater of ideals. There are ideals in society that we do not really expect people to live up to. Yet, if they are stated in law, we may believe that people will try to live up to them, even though as a practical matter we know that they will fail and violate the ideals. Now, that is a profoundly Italian attitude toward law, and a profoundly un-American one. It is a functional attitude toward law. But it requires of law a very different function from that required of American law, which does things rather than state ideals.

I would like to give you a couple of examples of attitudes that may show what I mean about this. One modern problem for many legal systems is how to deal with tragic situations like those that involve the allocation of artificial kidneys. There are not enough to go around, or until recently there were not; now it is said both in Italy and in America, that there are enough to go around, but until recently there clearly were not. And the question was, who would get to have an artificial kidney, given that life or death depended on it, but not everyone could have one? In Italy, the attitude, stated in laws, was that no choices should be made. It should be "First come, first served." Everyone was equal so long as the supply lasted; whoever needed it should come and get it. Why? Because all human beings were the same. That is the ideal. In the United States, in a variety of ways using a variety of legal methods, the attempt was made to allocate kidneys to those who, if they got them, would have the greatest chance of surviving longest. A nice, functional goal- "We haven't got enough; let's use them in the most efficient way."

The same thing happens with respect to universities. In Italy, the Constitution states that the universities are open to everyone; to everyone, not to the brightest, but to everyone who has finished the appropriate previous education and can pass an entrance exam, which is not an exam that qualifies people particularly according to skill. In the United States, that is not the way it works. Our whole system of pri- 
vate/public education is a career open to talent. Again, it is a system based on efficiency rather than straight egalitarianism.

Now, as a practical matter, it may well be that the results in Italy are less egalitarian than they are in the United States. It may be that, because our system is not stated in terms of an ideal, there are in fact more scholarships, more attempts to help the disadvantaged get an education in the United States than in Italy. And it may be that in Italy, because everyone can go to the university, the universities become so crowded that only those who can either pay for private lessons or who can get close to professors, can get a really first-rate education. The result, in practice, may be far less egalitarian there than here. The same may be true with kidneys. It may be that in practice when one states an ideal like "First come, first served," which means that somebody may get the kidney even though he or she is dying of another disease, even though he or she has much less of a chance of surviving on the artificial kidney than someone else who may come along later, that one in practice permits doctors to play around in a variety of different ways. And it may be that such playing around permits the introduction of allocation systems that would be thought of as improper, like "Somebody gave a lot of money, why not give him a kidney?" Such an allocation would obviously not meet the stated ideal.

The Italian, or perhaps the Italian legal scholar, would likely answer this implied criticism by saying, "But at least the ideal which the law stated was a good one, and the practice both in Italy and in the United States is going to be compromised, is going to be poor, anyway. It is more important that law state the ideal than that it be lived up to, because the practice is always going to be second-rate, at best."

There are a lot of other examples of the same thing one could use; the role of juries in the United States-we use juries, and sometimes even judges, to give us results without giving us reasons. Why? Because we cannot stand to know the reasons. We want to know that somebody should go to jail and somebody should not; somebody should be acquitted even though the law may state that what he did was a crime. But we don't really want to know clearly what those laws are, because we have conflicting ideals, and we cannot stand a too clear statement of those conflicting ideals. In Italy, that is viewed as a compromise. It would be viewed as totally, totally wrong. There, sentencing is not left up to juries, not even left up to judges. Instead, a wide number of aggravating factors and mitigating factors that attempt to control the judge's discretion when the judge comes to sentencing are developed. Because that way (even though we know that in practice the judge will ignore them) the law is stating the ideal of equal justice for everyone if the circumstances are the same. When one accepts a jury system, one accepts a system that cannot possibly 
be equal justice for everyone; it depends on the pick of the draw for twelve good people and true, and whether they happen to be influenced one way or another. In practice, we think that the jury is going to be a fairer system; not a perfect system, not an ideal system, but a fairer system. To which the Italian, I suppose, from his point of view, would answer again, "That isn't the object of law. Practicality always comes second. The object of law is to state ideals as to human behavior, ideals of treating everyone alike. This can only be done by systems that, by employing concepts of aggravating and mitigating circumstances, force judges to explain what they are doing. No such thing can come from a jury which is aresponsible in the sense that it never tells you why it decided as it did. Jury verdicts must inevitably deviate from law as stater of ideals."

Now, in fact, we sometimes find that kind of attitude even in the United States. We find that kind of attitude, for instance, in the capital punishment cases, where one of the criticisms that was made of capital punishment by the Supreme Court was that juries decided who should be sentenced to death without any rhyme or reason. In those cases, Mr. Justice Stewart said, "Whether one is sentenced to death or not is a matter as uncertain as being hit by lightning." Like being hit by lightning, that cannot be right. Just leaving it in the hands of people who tell us, "This one should be picked as against that one," violates a fundamental ideal. That attitude, that almost Italian attitude, is understandable in as dramatic a situation as that of capital punishment. And the reverse of it is also understandable. The other criticism that was made in the United States of capital punishment cases was that juries in fact did develop a pattern, a pattern of discrimination against particular ethnic or racial groups, in capital punishment cases, and that that pattern was certainly less than ideal. If, instead, we could force legislatures to state what the requirements were for this most draconic of punishments, then at least in this awful area the law would be stated clearly. It would be a bad situation, but at least it would be treated in idealized terms and recognize that people ought to be treated equally.

Now, Italy does not have a problem with capital punishment because, in its functional period way back at the time of Beccaria, it decided that capital punishment didn't serve any purpose. And that functional period lasted long enough so that when Italy was unified, Tuscany refused to join the Italian Kingdom unless prohibition of capital punishment was made a part of the fundamental law of that kingdom. Capital punishment was one of the few "functional" things as to which Fascism had its way. It managed to reintroduce the death penalty. But after the War, Italy went back to its tradition, and abolished the death penalty again. While Italy does not have this particular problem, it applies the same reasoning to every form of criminal pun- 
ishment. "All penalties ought to be stated in ways that represent the ideal of equal justice for everyone." Now, as I've said, if you have law stated in such idealistic terms, it is going to be very difficult for it to be followed. Because ideals are beyond human beings. Individual judges will be prejudiced there, as they can be prejudiced here. They may be responsive to political pressure; they may even be "buyable." And if that is so, the ideal won't work in practice at all. However, if the object is to state an ideal, that doesn't matter. Of course, when you have many deviations, based on the fallibility of humans, from the "ideal," it is also very easy to become cynical about law. It becomes easy to say that the law as it is written (though it is uncriticizable) cannot be followed. And hence, it becomes easy to have contempt for law. It does not do things, it is simply philosophy. And there we are.

Now where does all this leave us? I think it leaves us that criticism of Italian law as being sterile, formalistic, and unresponsive to social needs is unhistorical and does not take into account the fact that this very unresponsiveness was the best way to respond to democratic aspirations during Fascism. Similarly, it does not consider one function of law, more emphasized in Italy than here; and that is law and legal systems as staters and protectors of ideals that humans necessarily botch up and fail to live up to in practice. Large areas of Italian law since the fall of Fascism have become more obviously functional and responsive-preeminently constitutional law. And this movement continues and is likely to grow. Yet at some point, the issue of whether law is more important for what it does or what ideals it states has to be faced, and on this issue U.S. and Italian views are likely to continue to differ fundamentally. 